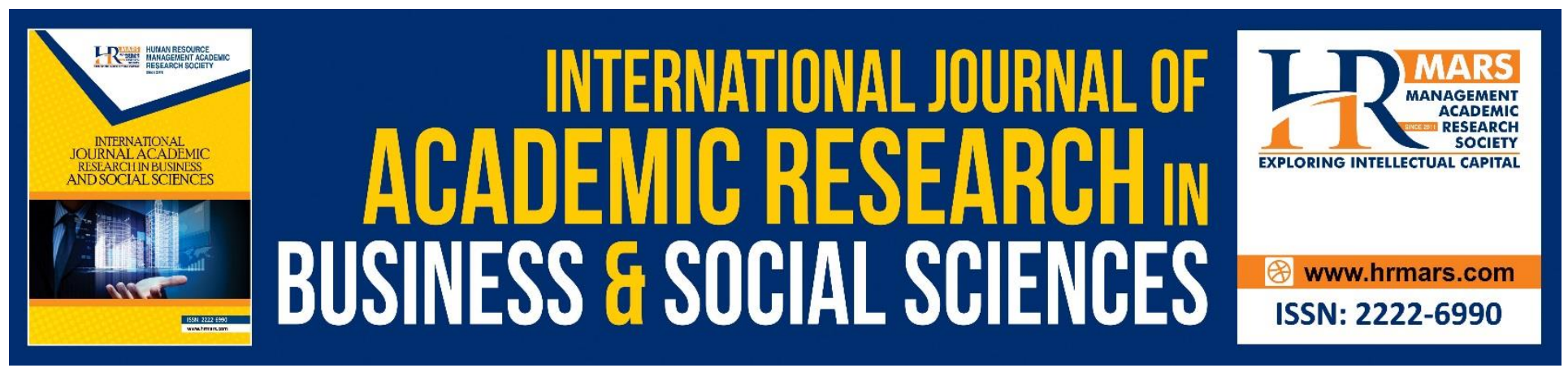

\title{
The Influence of Perceptions of Training towards Affective Commitment: A Conceptual Paper
}

Mikkay Wong Ei Leen, Rabeatul Husna Abdull Rahman, Halimah Mohd Yusof, Umar Haiyat Abdul Kohar

To Link this Article: http://dx.doi.org/10.6007/IJARBSS/v8-i7/4332

DOI: $\quad 10.6007 /$ IJARBSS/v8-i7/4332

Received: 27 May 2018, Revised: 19 June 2018, Accepted: 29 June 2018

Published Online: 08 July 2018

In-Text Citation: (Leen, Rahman, Yusof, \& Kohar, 2018)

To Cite this Article: Leen, M. W. E., Rahman, R. H. A., Yusof, H. M., \& Kohar, U. H. A. (2018). The Influence of Perceptions of Training towards Affective Commitment: A Conceptual Paper. International Journal of Academic Research in Business and Social Sciences, 8(7), 165-171.

Copyright: (C) 2018 The Author(s)

Published by Human Resource Management Academic Research Society (www.hrmars.com)

This article is published under the Creative Commons Attribution (CC BY 4.0) license. Anyone may reproduce, distribute, translate and create derivative works of this article (for both commercial and non-commercial purposes), subject to full attribution to the original publication and authors. The full terms of this license may be seen

at: http://creativecommons.org/licences/by/4.0/legalcode

Vol. 8, No. 7, July 2018, Pg. 165 - 171

http://hrmars.com/index.php/pages/detail/IJARBSS

JOURNAL HOMEPAGE

Full Terms \& Conditions of access and use can be found at http://hrmars.com/index.php/pages/detail/publication-ethics 


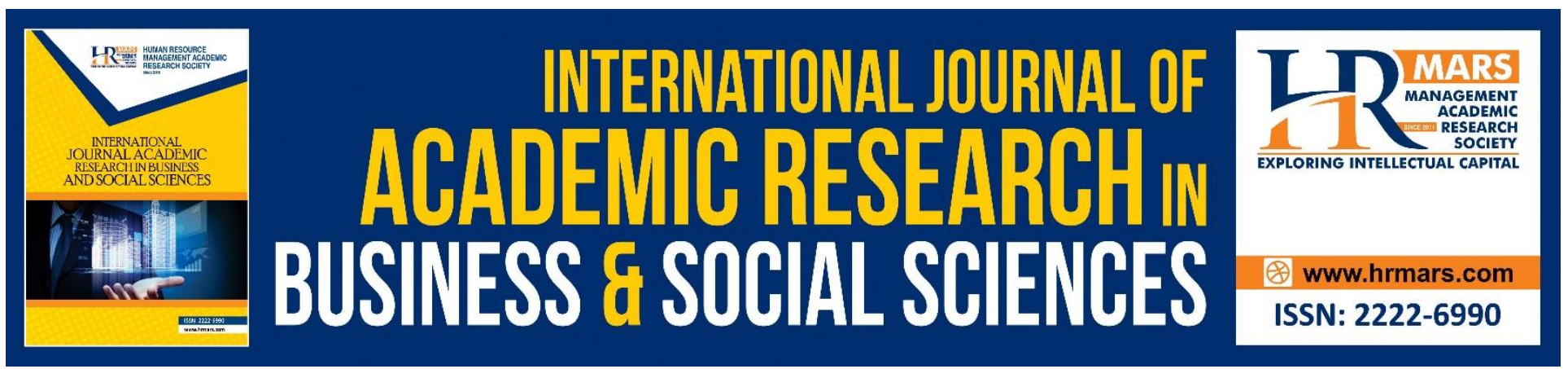

\title{
The Influence of Perceptions of Training towards Affective Commitment: A Conceptual Paper
}

\author{
Mikkay Wong Ei Leen \\ Faculty of Management, Universiti Teknologi Malaysia,Malaysia \\ Rabeatul Husna Abdull Rahman \\ Faculty of Management, Universiti Teknologi Malaysia, Malaysia \\ Halimah Mohd Yusof \\ Faculty of Management, Universiti Teknologi Malaysia, Malaysia \\ Umar Haiyat Abdul Kohar \\ Faculty of Management, Universiti Teknologi Malaysia, Malaysia
}

\begin{abstract}
This paper proposes to investigate the influence of perceptions of training towards affective commitment. Furthermore, this study focuses on employees' perceptions of training as investigating employees' perceptions was identified as an alternative to determine the relationship between training and employees' attitude and work-related behavior. Apart from that, it was noted in the literature that there remains insufficient empirical evidence explaining how perceptions of training influences affective commitment. The respondents of this study are engineers from the Malaysian manufacturing sector. Obtained data will be analyzed using the structural equation modelling (PLSSEM). Theoretically, this study contributes to the literature on the influence of perceptions of training towards affective commitment among engineers in Malaysia.
\end{abstract}

Keywords: Engineers, Perceptions of Training, Training, Organizational Commitment, Affective commitment

\section{Introduction}

Irrespective of the nature of an organization, training is among the backbone towards establishing a successful organization. In consonance to Bulut and Culha (2010), it is salient for organizations to invest in training as it plays an imperative role in increasing their employees' skills, knowledge, attitude and behavior. Investment in training programs are beneficial as training acts a platform to develop organizational performance and intellectual capital of the organization (Bulut and Culha, 2010). 
INTERNATIONAL JOURNAL OF ACADEMIC RESEARCH IN BUSINESS AND SOCIAL SCIENCES Vol. 8, No. 7, July 2018, E-ISSN: 2222-6990 @ 2018 HRMARS

Generally, "training" dimension is the key dimension employed in examining employees' attitude and work-related behavior (Meyer and Allen, 1997). However, in recent years, it was observed that the number of studies which employed employees' perceptions is increasing gradually. This is primarily due to the understanding that employees' attitudes and behaviors are substantially impelled by their perceptions (Guest, 2002). It was further supported by Dysvik and Kuvaas (2008) that employees' perception is an alternative to assess the relationship between training and attitudes as well as their work-related behavior.

Hence, in this study, there are seven dimensions of perceptions of training was employed perceived access to training, perceived supervisor support for training, perceived co-worker support for training perceived benefits of training, perceived training comprehensiveness, perceived competence mobilization and motivation to learn.

Perceived access to training denotes employees' belief that they can attend training programs without any constraints imposed by their organization (Alamri and Al-Duhaim, 2017; Yang, Sanders, and Bumatay, 2012). The relationship formed between an employee with their supervisors and coworkers are represented by perceived supervisor support for training (Alamri and Al-Duhaim, 2017; Wright and Gardner, 2003) and perceived co-worker support for training (Alamri and Al-Duhaim, 2017; Bulut and Culha, 2010), respectively. Relying upon the formed relationship between supervisors and co-workers, employees would be able to request training from their supervisor as well as cooperate with their co-workers to further develop their skills obtained from training programs. Following that, perceived benefits of training signifies an employee's belief on the benefits that they would gain through training. An employee's perception on the degree of extensiveness of training programs provided by an organization refers to perceived training comprehensiveness (Srivastava and Dhar, 2015; Xerri and Reid, 2018). Next, perceived competence mobilization is employees' belief that they have the right and opportunity to apply newly attained knowledge and skills through training programs (Lai and Kapstad, 2009; White Ellis and Peno, 2017). Lastly, motivation to learn was defined as the degree of enthusiasm and willingness to learn new knowledge and skills through training programs provided by the organization (Ocen, Francis, and Angundaru, 2017).

Past studies indicated that human resource management (HRM) practices influences employees' attitude and behavior positively (Jehanzeb, Abdul Hamid, and Rasheed, 2015; Kehoe and Wright, 2013). The positive relationship is attributed to the employees' belief that their contribution is being appreciated and their well-being is prioritized by the organization. This, in turn, would influence their degree of organizational commitment.

Organizational commitment comprises of three key dimensions, specifically, affective commitment, normative commitment and continuance commitment. However, this study focuses solely on affective commitment. In consonance to Rhoades, Eisenberger, and Armeli (2001), affective commitment is the psychological bond formed between an employee and the organization. Moreover, employees with high degree of affective commitment are more likely to have high sense of belonging and identification with the organization. This leads towards increment in their intention to align their values with the organizational values (Wright and Nishii, 2006).

\section{Problem Statement}

Over the years, the number of studies investigating employees' perceptions have gradually increased. However, Yang et al. (2012) and Rhoades et al. (2001) urged for more studies to be conducted on the individual-level outcomes of employee perceptions towards human resource 
INTERNATIONAL JOURNAL OF ACADEMIC RESEARCH IN BUSINESS AND SOCIAL SCIENCES Vol. 8, No. 7, July 2018, E-ISSN: 2222-6990 @ 2018 HRMARS

practices. Irrefutably, there have been studies conducted on the relationship between perceived access to training, perceived supervisor support for training, perceived co-worker support for training, perceived benefits of training and motivation to learn with affective commitment. However, these studies were conducted in the Western context. It is imperative to note that Westerners and Malaysians are known to practice different work attitude and characteristics - the former practices individualism and the latter practices collectivism.

In spite of the importance of perceived training comprehensiveness and perceived competence mobilization, it was observed that these dimensions are often neglected. Thus, Guest (2002) and Lai and Kapstad (2009) calls for more studies to be conducted utilizing these dimensions. Consequently, this study fulfils the need to investigate the influence of employees' perceptions of training towards affective commitment.

The motivation of this paper to enlighten the influence of engineer's perceptions of training towards their affective commitment from the Malaysian context. Irrefutably, there were studies conducted in the past which utilized these dimensions; however, past studies were conducted in the Western context (Ahmad and Bakar, 2003). It is critical to note that Westerners and Malaysians are known to practice different sets of work attitude and characteristics, where the former practices individualism and the latter practices collectivism (Jariya, 2012; Sinha, 2014).

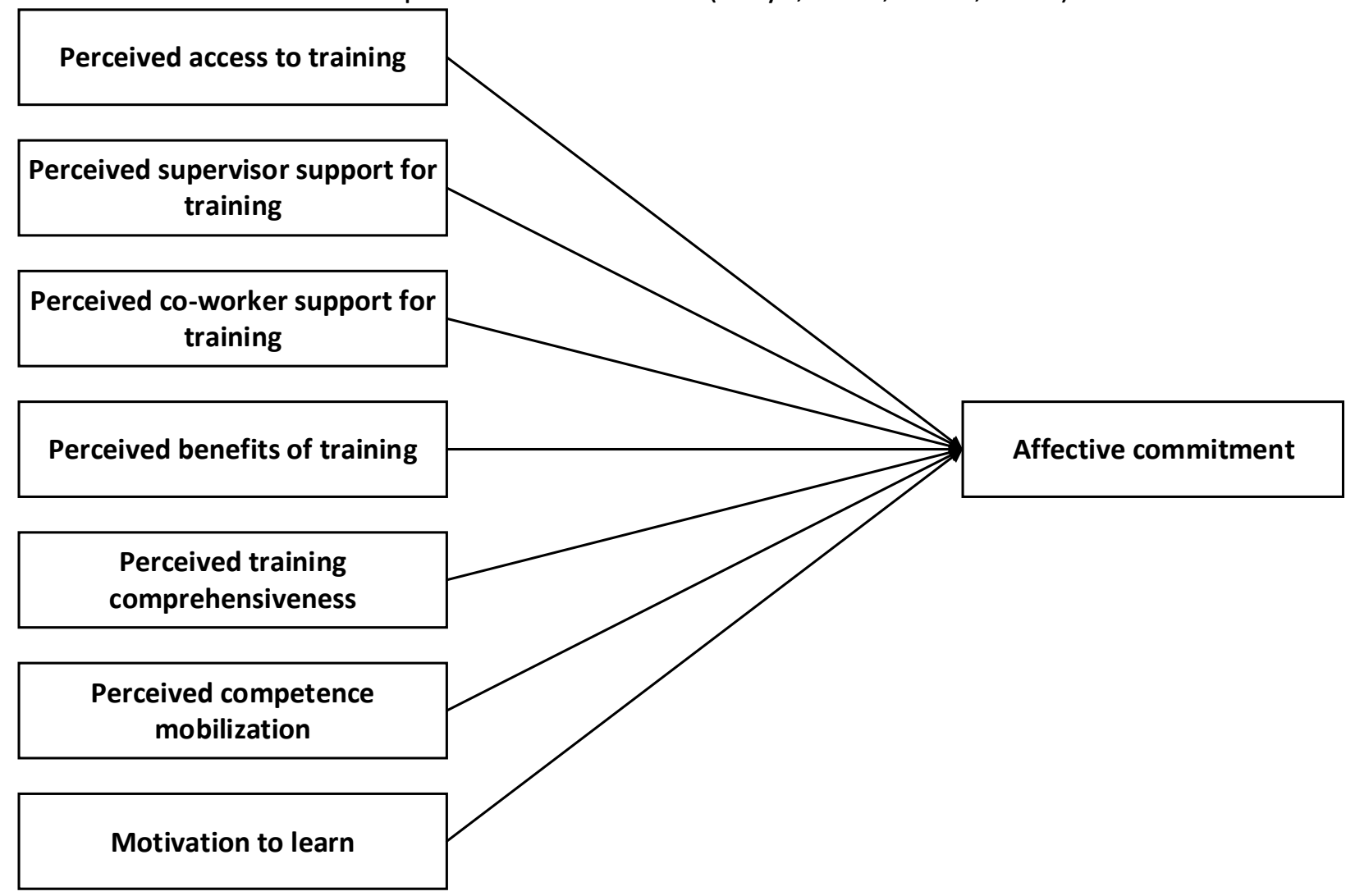

Figure 1: Proposed conceptual framework 
INTERNATIONAL JOURNAL OF ACADEMIC RESEARCH IN BUSINESS AND SOCIAL SCIENCES

Vol. 8, No. 7, July 2018, E-ISSN: 2222-6990 (C) 2018 HRMARS

\section{Research Questions}

1) What is the correlation between perceived access to training and affective commitment?

2) What is the correlation between perceived supervisor support for training and affective commitment?

3) What is the correlation between perceived co-worker support for training and affective commitment?

4) What is the correlation between perceived benefits of training and affective commitment?

5) What is the correlation between perceived competence mobilization and affective commitment?

6) What is the correlation between perceived training comprehensiveness and affective commitment?

7) What is the correlation between motivation to learn and affective commitment?

\section{Research Objectives}

1) To determine the correlation between perceived access to training and affective commitment

2) To determine the correlation between perceived supervisor support for training and affective commitment

3) To determine the correlation between perceived co-worker support for training and affective commitment

4) To determine the correlation between perceived benefits of training and affective commitment

5) To determine the correlation between perceived competence mobilization and affective commitment

6) To determine the correlation between perceived training comprehensiveness and affective commitment

7) To determine the correlation between motivation to learn and affective commitment

\section{Methodology}

In order to determine the relationship between perceptions of training (perceived access to training, perceived supervisor support for training, perceived co-worker support for training, perceived benefits of training, perceived training comprehensiveness, perceived competence mobilization, and motivation to learn) and affective commitment, this study employed the quantitative method. This method is capable to impart summaries of data which support generalization about the study. Additionally, this study is an exploratory based study and crosssectional survey design - will assist the study of the relationship between perceptions of study and affective commitment. Furthermore, as depicted in Table 1, the respondents of this study are engineers from the Malaysian manufacturing sector. 
INTERNATIONAL JOURNAL OF ACADEMIC RESEARCH IN BUSINESS AND SOCIAL SCIENCES Vol. 8, No. 7, July 2018, E-ISSN: 2222-6990 @ 2018 HRMARS

\begin{tabular}{|l|l|}
\hline $\begin{array}{l}\text { Target } \\
\text { Population }\end{array}$ & Engineers \\
\hline Sampling Frame & $\begin{array}{l}\text { Engineers from the Malaysian manufacturing } \\
\text { sector }\end{array}$ \\
\hline $\begin{array}{l}\text { Sampling } \\
\text { Method }\end{array}$ & Convenience sampling method \\
\hline $\begin{array}{l}\text { Data Collection } \\
\text { Method }\end{array}$ & Distribution of questionnaires \\
\hline
\end{tabular}

Table 1: Data collection procedure

\section{Data Analysis}

In accordance to Byrne and van De Vijver (2010), most researchers employed the structural model to explain causal relationship among variables. This method illustrates models using path diagrams. Apart from demonstrating different relationships among variables, it is capable to simultaneously test them.

Hypothesis testing will be conducted through the adaptation of structural model. The structural model can be validated using coefficient of determination $\left(R^{2}\right)$, predictive relevance $\left(Q^{2}\right)$, size and significance of path coefficients, effect size $\left(f^{2}\right)$ and path coefficients. The decision to accept or reject proposed hypothesis are dependent on the results of path coefficients, $p$-values and t-values with significance level of 0.05 . Hence, this study will be utilizing the structural model in analyzing proposed hypotheses.

\section{Conclusion}

In a nutshell, this study accumulates key dimensions for perceptions of training and proposes a framework to determine the influence of these dimensions towards employees' affective commitment. This study intends to uncover the influence of perceptions of training towards employees' affective commitment.

\section{Acknowledgement}

The authors would like to acknowledge the Malaysian Ministry of Higher Education (MyBrain 15) for funding this study.

\section{Corresponding Author}

Mikkay Wong Ei Leen, Faculty of Management, Universiti Teknologi Malaysia, Malaysia, Email: mikkay_wong@live.com.my

\section{References}

Ahmad, K. Z., \& Bakar, R. A. (2003). The Association between Training and Organizational Commitment among White-collar Workers in Malaysia. International Journal of Training and Development, 7(3), 166-185.

Alamri, M. S., \& Al-Duhaim, T. I. (2017). Employees Perception of Training and Its Relationship with Organizational Commitment among the Employees Working at Saudi Industrial Development Fund. International Journal of Business Administration, 8(2), 25.

Bulut, C., \& Culha, O. (2010). The Effects of Organizational Training on Organizational Commitment. International Journal of Training and Development, 14(4), 309-322. 
INTERNATIONAL JOURNAL OF ACADEMIC RESEARCH IN BUSINESS AND SOCIAL SCIENCES Vol. 8, No. 7, July 2018, E-ISSN: 2222-6990 @ 2018 HRMARS

Byrne, B. M., \& van De Vijver, F. J. R. (2010). Testing for Measurement and Structural Equivalence in Large-scale Cross-cultural Studies: Addressing The Issue of Nonequivalence. International Journal of Testing, 10(2), 107-132.

Dysvik, A., \& Kuvaas, B. (2008). The relationship between perceived training opportunities, work motivation and employee outcomes. International Journal of Training and Development, 12(3), 138-157.

Guest, D. (2002). Human Resource Management, Corporate Performance and Employee Wellbeing: Building the Worker into HRM. Journal of Industrial relations, 44(3), 335-358.

Jariya, A. I. (2012). Western cultural values and its implications on management practices. South East Asian Journal of Contemporary Business, Economics and Law, 1(2012), 61-70.

Jehanzeb, K., Abdul Hamid, A. B., \& Rasheed, A. (2015). What Is the Role of Training and Job Satisfaction on Turnover Intentions? International Business Research, 8(3), 208-221.

Kehoe, R. R., \& Wright, P. M. (2013). The impact of high-performance human resource practices on employees' attitudes and behaviors. Journal of Management, 39(2), 366-391.

Lai, L., \& Kapstad, J. C. (2009). Perceived competence mobilization: an explorative study of predictors and impact on turnover intentions. The International Journal of Human Resource Management, 20(9), 1985-1998.

Meyer, J. P., \& Allen, N. J. (1997). Commitment in the workplace: Theory, research and application. London, UK SAGE.

Ocen, E., Francis, K., \& Angundaru, G. (2017). The role of training in building employee commitment: the mediating effect of job satisfaction. European Journal of Training and Development, 41(9), 742-757.

Rhoades, L., Eisenberger, R., \& Armeli, S. (2001). Affective Commitment to the Org the contribution of perceived organizational support. Journal of Applied Psychology, 86(5), 825-836.

Sinha, J. B. P. (2014). Collectivism and Individualism. In J. B. P. Sinha (Ed.), Psycho-Social Analysis of the Indian Mindset (pp. 27-51). New Delhi: Springer India.

Srivastava, A. P., \& Dhar, R. L. (2015). Training comprehensiveness: construct development and relation with role behaviour. European Journal of Training and Development, 39(7), 641-662.

White Ellis, C., \& Peno, K. (2017). How Businesses Can Cultivate Engaged, Committed Employees.

Wright, P. M., \& Gardner, T. M. (2003). The human resource-firm performance relationship: methodological and theoretical challenges The new workplace: A guide to the human impact of modern working practices (pp. 311-328). New York Wiley New York.

Wright, P. M., \& Nishii, L. H. (2006). Strategic HRM and organizational behavior: Integrating multiple levels of analysis. CAHRS Working Paper Series, 1-26. Retrieved from

Xerri, M. J., \& Reid, S. R. M. (2018). Human Resources And Innovative Behaviour: Improving Nursing Performance. International Journal of Innovation Management, 22(02), 1850019.

Yang, H., Sanders, K., \& Bumatay, C. P. (2012). Linking perceptions of training with organizational commitment: The moderating role of self-construals. European Journal of Work and Organizational Psychology, 21(1), 125-149. 